\title{
SYNTHESIS, CHARACTERIZATION, AND ANTIMICROBIAL EVALUATION OF NEW N-PHENYLCINNAMAMIDE DERIVATIVES LINKED TO ASPIRIN AND IBUPROFEN
}

\author{
AMEER H ALWASH ${ }^{1 *}$, ALAA M MAHDI ${ }^{2}$, HAIDER J AL-KARAGULLY ${ }^{1}$ \\ ${ }^{1}$ Department of Pharmaceutical Chemistry, College of Pharmacy, Albayan University, Baghdad, Iraq. ${ }^{2}$ Department of Pharmacy, Alrasheed \\ University College, Baghdad, Iraq. Email: ameloride@yahoo.com \\ Received: 26 April 2018, Revised and Accepted: 03 July 2018
}

\section{ABSTRACT}

Objective: The objective of this study was to synthesize phenylcinnamamide (substituted acetanilide chalcone) derivatives linked to aspirin and ibuprofen with potential antibacterial and antifungal activity.

Methods: Substituted acetanilide compounds were reacted with different arylaldehydes through Claisen-Schmidt condensation in the presence of $\mathrm{KOH}$. They formed differently substituted acetanilide chalcones (1a-e) which are linked to aspirin and ibuprofen through an ester linkage to form compounds (2a-j) using ethyl chloroformate (ECF) as a catalyst.

Results: The synthesized compounds have been characterized by elemental analysis, Fourier transform infrared and ${ }^{1} \mathrm{H}$-nuclear magnetic resonance spectroscopy. An antibacterial evaluation was achieved for Gram-positive bacteria (Staphylococcus aureus) and Gram-negative bacteria (Escherichia coli) and antifungal for Candida albicans.

Conclusion: Compounds (2a-j) have shown intermediate antimicrobial activity against different strains of microorganisms.

Keywords: Acetanilide, Claisen-Schmidt condensation, Chalcones, Aspirin, Ibuprofen, Antibacterial, Antifungal.

(C) 2018 The Authors. Published by Innovare Academic Sciences Pvt Ltd. This is an open access article under the CC BY license (http://creativecommons. org/licenses/by/4. 0/) DOI: http://dx.doi.org/10.22159/ajpcr.2018.v11i10.26937

\section{INTRODUCTION}

Antimicrobial drugs are compounds which antagonize the survival or growth of a variety of microorganisms such as bacteria, viruses, fungi, and parasite [1]. Benzalacetophenone (or benzylidene acetophenone) is the central core for a variety of important biological compounds which known as a group (chalcones or chalconoids). Chalcone is a captivating moiety which consists of two aromatic rings linked by enone bridge (or $\alpha, \beta$-unsaturated ketone) and it belongs to flavonoid family [2]. The existence of conjugated chromophore (-CO- $\mathrm{CH}=\mathrm{CH}-)$ and other auxochromes have made them colored compounds [3]. C-H・ $\pi$ (arene) hydrogen bonds along the $\mathrm{c}$ axis give the molecule a zigzag shape [4]. The synthesis and biodynamic activities of chalcones were the cornerstones of many kinds of scientific researches around the world [5]. They could be prepared synthetically or naturally (like another flavonoid family) from plants [6]. Several methods have been described for the chemical synthesis of chalcones such as Claisen-Schmidt, Knoevenagel condensations and the Meyer-Schuster rearrangement [7-9]. The conjugated ketoethylenic bridge has an important role in the behavior of chalcone moiety due to the delocalization of $\pi$ electrons between two benzene rings through a bridge which gives it a flexibility in electrons movement during reactions [10], consequently it serves as starting materials for many heterocyclic compounds and therapeutic substances which are used for healing of a lot of illnesses [11]. Chalcones show diversity of pharmacological activities such as anticancer [12], cytotoxic [13], antibacterial [14], antiviral [15,16], and antifungal [17,18].

Nonsteroidal anti-inflammatory drugs (NSAIDs) are popular nonopiate compounds used worldwide for the treatment of pain, fever, and inflammation [19]. Their mechanism of action involves interfering with the cyclooxygenase (COX) pathway, which includes the conversion of arachidonic acid by the enzyme COX to prostaglandins [20]. Ibuprofen is a chiral molecule which is a derivative of phenyl propionic acid, while, aspirin is a salicylate derivative [21]. Various studies have shown potential antibacterial and antifungal activities in aspirin and ibuprofen $[22,23]$.
Based on these observations, an attempt was considered to link aspirin or ibuprofen to differently substituted acetanilide chalcones that may afford a synergistic effect with potential antimicrobial activity. These novel conjugates would be prepared by cross-linking of these molecules through an ester bond.

\section{METHODS}

Acetanilide, benzaldehyde, p-chlorobenzaldehyde, p-nitrobenzaldehyde, vanillin, and p-hydroxybenzaldehyde were purchased from Hi-Media (India). Acetaminophen, ibuprofen, aspirin, ampicillin, and ketoconazole were donated thankfully by The State Company for Drug Industries (SDI, Samara, Iraq). Melting points were determined (uncorrected) using electrical melting point apparatus, Electrothermal 9300, USA. The infrared spectra were performed in $\mathrm{KBr}$ disc in the range of 400-4000 $\mathrm{cm}^{-1}$ by Fourier transform-infrared (FTIR) spectrophotometer/Biotech engineering management Co. Ltd (UK). ${ }^{1} \mathrm{H}$-nuclear magnetic resonance (NMR) spectra were recorded using NMR Bruker $500 \mathrm{MHz}$ - Avance III and chemical shifts were recorded in parts per million (ppm) downfield using tetramethylsilane as an internal reference. Furthermore, elemental microanalyses (CHN) were performed by EuroVector EA 3000 A, Italy, and the percentage of elements was found to be close to that of the calculated values. Physical and spectral data of the synthesized compounds are recorded in Table 1.

\section{Chemical syntheses}

The synthesis of target compounds (1a-e and 2a-j) was achieved, as illustrated in Schemes 1 and 2.

\section{Chemical synthesis of compounds 1a-e [24]}

Equimolar quantities $(0.01 \mathrm{~mol})$ of substituted acetanilide compound and aryl aldehyde were dissolved in minimum volume of ethanol followed by the addition of $\mathrm{KOH}$ solution $(40 \%)$ slowly over $10 \mathrm{~min}$ with stirring for $4 \mathrm{~h}$ and kept overnight. The reaction mixture was evaporated and acidified with cold $10 \% \mathrm{HCl}$ and washed with cold 
Table 1: Physical and spectral data of the titled compounds

\begin{tabular}{|c|c|}
\hline & $\begin{array}{l}\text { 1.F: } \mathrm{C}_{15} \mathrm{H}_{13} \mathrm{NO}_{2} \text {, M.Wt: } 239.27, \mathrm{~m} . \mathrm{p}: 184-186^{\circ} \mathrm{C} \text {, yield: } 81 \% \text {, elemental analysis: } \mathrm{C}-72.1 \%, \mathrm{H}-5.3 \% \text {, and } \mathrm{N}-5.95 \% \text {. } \\
\text { HNMR }(\mathrm{ppm}): 9.23(\mathrm{~s}, 1 \mathrm{H},-\mathrm{NH}-\mathrm{C}=0), 6.55-7.65\left(\mathrm{~m}, 9 \mathrm{H} \text {, aromatic), } 9.67(\mathrm{~s}, 1 \mathrm{H},-\mathrm{OH}), 7-7.65(\mathrm{~d}, 2 \mathrm{H}, \mathrm{CH}=\mathrm{CH}=\mathrm{C}=0) . \mathrm{IR}^{-1}\left(\mathrm{~cm}^{-1}\right) \text { : }\right. \\
130(\mathrm{OH}), 1640(\mathrm{C}=0), 1605(\mathrm{C}=\mathrm{C}) \text { trans-alkene, } 3300(-\mathrm{NH})\end{array}$ \\
\hline & $\begin{array}{l}\mathrm{F}: \mathrm{C}_{16} \mathrm{H}_{15} \mathrm{NO}_{3,} \text { M.wt: } 369.3 \text {, m.p: 201-203 }{ }^{\circ} \mathrm{C} \text {, yield: } 84 \% \text {, elemental analysis: } \mathrm{C}-73.66 \%, \mathrm{H}-5.45 \%, \mathrm{~N}-5.64 \% .{ }^{1} \mathrm{HNMR}(\mathrm{ppm}): \\
23,(\mathrm{~s}, 1 \mathrm{H},-\mathrm{NH}-\mathrm{C}=\mathrm{O}), 6.8-7.55(\mathrm{~m}, 8 \mathrm{H} \text {, aromatic), } 9.5(\mathrm{~s}, 1 \mathrm{H},-\mathrm{OH}), 7.05-7.36(\mathrm{~d}, 2 \mathrm{H}, \mathrm{CH}=\mathrm{CH}=\mathrm{C}=\mathrm{O}), 3.82(\mathrm{~s}, \\
\left.\mathrm{H},-\mathrm{OCH}_{3}\right) \text {. IR }\left(\mathrm{cm}^{-1}\right): 3125(-\mathrm{OH}), 1635(\mathrm{C}=0), 1600(\mathrm{C}=\mathrm{C}) \text { trans-alkene, } 3295(\mathrm{NH}), 1090(\mathrm{C}-\mathrm{O}-\mathrm{C}), 2950,2870(\mathrm{C}-\mathrm{H}) \\
\text { ymmetrical (asym.) and symmetrical (sym.) stretching vibration of }-\mathrm{CH}_{3} \text { group }\end{array}$ \\
\hline & $\begin{array}{l}\text { M.F: } \mathrm{C}_{15} \mathrm{H}_{13} \mathrm{NO}_{2} \text {, M.wt: } 239.27 \text {, m.p: } 179-181^{\circ} \mathrm{C} \text {, yield: } 79 \% \text {, elemental analysis: } \mathrm{C}-71.9 \%, \mathrm{H}-5.34 \%, \mathrm{~N}-6.25 \% .{ }^{1} \mathrm{HNMR}(\mathrm{ppm}): \\
9.23(\mathrm{~s}, 1 \mathrm{H},-\mathrm{NH}-\mathrm{C}=0), 6.76-7.6\left(\mathrm{~m}, 9 \mathrm{H} \text {, aromatic), } 9.46(\mathrm{~s}, 1 \mathrm{H},-\mathrm{OH}), 7.1-7.52(\mathrm{~d}, 2 \mathrm{H}, \mathrm{CH}=\mathrm{CH}=\mathrm{C}=0) . \mathrm{IR}\left(\mathrm{cm}^{-1}\right): 3135(-\mathrm{OH}) \text {, }\right. \\
1635(\mathrm{C}=0), 1603(\mathrm{C}=\mathrm{C}) \text { trans-alkene, } 3290(\mathrm{NH})\end{array}$ \\
\hline & $\begin{array}{l}\mathrm{F}: \mathrm{C}_{15} \mathrm{H}_{12} \mathrm{~N}_{2} \mathrm{O}_{4} \text {, M.wt: } 284.27, \mathrm{~m} . \mathrm{p}: 225-227^{\circ} \mathrm{C} \text {, yield: } 72 \% \text {, elemental analysis: } \mathrm{C}-60.2 \%, \mathrm{H}-4.59 \%, \mathrm{~N}-10.38 \% . \\
\text { INMR (ppm): } 9.23(\mathrm{~s}, 1 \mathrm{H},-\mathrm{NH}-\mathrm{C}=0), 8.37\left(\mathrm{~d}, 2 \mathrm{H} \text {, aromatic, ortho to } \mathrm{NO}_{2}\right), 8.07\left(\mathrm{~d}, 2 \mathrm{H}, \text { aromatic, meta to } \mathrm{NO}_{2}\right), 6.75(\mathrm{~d} \text {, } \\
\mathrm{H} \text {, aromatic, ortho to } \mathrm{OH}), 7.4(\mathrm{~d}, 2 \mathrm{H}, \text { aromatic, meta to } \mathrm{OH}), 9.44(\mathrm{~s}, 1 \mathrm{H},-\mathrm{OH}), 7.34,7.75(\mathrm{~d}, 1 \mathrm{H}, \alpha \text { and } \beta \mathrm{H}, \text { respectively). } \\
\left(\mathrm{cm}^{-1}\right): 3100(-\mathrm{OH}), 1630(\mathrm{C}=0), 1595(\mathrm{C}=\mathrm{C}) \text { trans-alkene, } 3295(\mathrm{NH}), 1550(\mathrm{~N}-\mathrm{O}) \text { asym. stretching, } 1342(\mathrm{~N}-\mathrm{O}) \text { sym. } \\
\text { retching }\end{array}$ \\
\hline & $\begin{array}{l}\mathrm{F}: \mathrm{C}_{15} \mathrm{H}_{12} \mathrm{ClNO}_{2}, \mathrm{M} . w \mathrm{t}: 273.72, \mathrm{~m} . \mathrm{p}: 201-203^{\circ} \mathrm{C} \text {, yield: } 72 \% \text {, elemental analysis: } \mathrm{C}-66.95 \%, \mathrm{H}-4.25 \%, \mathrm{~N}-5.88 \% \text {. } \\
\mathrm{NMR}(\mathrm{ppm}): 9.23(\mathrm{~s}, 1 \mathrm{H},-\mathrm{NH}-\mathrm{C}=0), 7.63 \mathrm{n}(\mathrm{d}, 2 \mathrm{H} \text {, aromatic, ortho to } \mathrm{Cl}), 7.7(\mathrm{~d}, 2 \mathrm{H} \text {, aromatic, meta to } \mathrm{Cl}), 6.75(\mathrm{~d}, 2 \mathrm{H} \text {, } \\
\text { omatic, ortho to } \mathrm{OH}), 7.38(\mathrm{~d}, 2 \mathrm{H}, \text { aromatic, meta to } \mathrm{OH}), 9.44(\mathrm{~s}, 1 \mathrm{H},-\mathrm{OH}), 7.05,7.62(\mathrm{~d}, 1 \mathrm{H}, \alpha \text { and } \beta \mathrm{H}, \text { respectively). } \\
\left(\mathrm{cm}^{-1}\right): 3095(-\mathrm{OH}), 1620(\mathrm{C}=0), 1590(\mathrm{C}=\mathrm{C}) \text { trans-alkene, } 3295(\mathrm{NH})(\mathrm{C}=0), 1600(\mathrm{C}=\mathrm{C}) \text { trans-alkene, } 1080 \\
\text { omatic }(\mathrm{C}-\mathrm{Cl}) \text { stretching vibration }\end{array}$ \\
\hline & $\begin{array}{l}\mathrm{F}: \mathrm{C}_{24} \mathrm{H}_{19} \mathrm{NO}_{5}, \text { M.wt: } 401.42, \mathrm{~m} . \mathrm{p}: 137-139^{\circ} \mathrm{C} \text {, yield: } 63 \% \text {, elemental analysis: } \mathrm{C}-74.07 \%, \mathrm{H}-4.54 \%, \mathrm{~N}-3.68 \% \cdot{ }^{1} \mathrm{HNMR}(\mathrm{ppm}): \\
22(\mathrm{~s}, 1 \mathrm{H},-\mathrm{NH}-\mathrm{C}=0), 7.33-8.25\left(\mathrm{~m}, 13 \mathrm{H} \text {, aromatic), } 7.05-7.52(\mathrm{~d}, 2 \mathrm{H}, \mathrm{CH}=\mathrm{CH}=\mathrm{C}=0), 2.4\left(\mathrm{~s}, 3 \mathrm{H},-\mathrm{CH}_{3}\right) . \mathrm{IR}^{-1}\left(\mathrm{~cm}^{-1}\right): 3028(-\mathrm{CH}\right. \\
\text { alkene), } 1748(\mathrm{C}=0 \text { of acetic ester }), 1727(\mathrm{C}=0 \text { of benzoic ester }), 1622(\mathrm{C}=0 \text { of amide }), 1600(\mathrm{C}=\mathrm{C}) \text { trans-alkene, }\end{array}$ \\
\hline & $\begin{array}{l}3300(\mathrm{NH}), 2940,2865(\mathrm{C}-\mathrm{H}) \text { asym. and sym. stretching vibration of }-\mathrm{CH}_{3} \text { group } \\
\text { M.F: } \mathrm{C}_{24} \mathrm{H}_{18} \mathrm{~N}_{2} \mathrm{O}_{7}, \mathrm{M} . w \mathrm{w}: 446.42, \mathrm{~m} . \mathrm{p}: 153-155^{\circ} \mathrm{C} \text {, yield: } 65 \% \text {, elemental analysis: } \mathrm{C}-66.97 \%, \mathrm{H}-4.33 \%, \mathrm{~N}-6.71 \% \text {. } \\
{ }^{1} \mathrm{HNMR}(\mathrm{ppm}): 9.22(\mathrm{~s}, 1 \mathrm{H},-\mathrm{NH}-\mathrm{C}=0), 7.3-8.4\left(\mathrm{~m}, 12 \mathrm{H} \text {, aromatic), } 7.35-7.75(\mathrm{~d}, 2 \mathrm{H}, \mathrm{CH}=\mathrm{CH}=\mathrm{C}=0), 2.38\left(\mathrm{~s}, 3 \mathrm{H},-\mathrm{CH}_{3}\right)\right. \\
\text { IR }\left(\mathrm{cm}^{-1}\right): 3025(-\mathrm{CH} \text { of alkene), } 1750(\mathrm{C}=0 \text { of acetic ester), } 1728(\mathrm{C}=0 \text { of benzoic ester }), 1620(\mathrm{C}=0 \text { of amide), } 1590(\mathrm{C}=\mathrm{C}) \\
\text { trans-alkene, } 3300(\mathrm{NH}), 1548(\mathrm{~N}-\mathrm{O}) \text { asym. stretching, } 1340(\mathrm{~N}-\mathrm{O}) \text { sym. stretching }\end{array}$ \\
\hline & $\begin{array}{l}\text { M.F: } \mathrm{C}_{24} \mathrm{H}_{18} \mathrm{ClNO}_{5}, \text { M.wt: } 435.86, \mathrm{~m} . \mathrm{p}: 145-147^{\circ} \mathrm{C} \text {, yield: } 67 \% \text {, elemental analysis: } \mathrm{C}-63.21 \%, \mathrm{H}-4.43 \%, \mathrm{~N}-3.39 \% \\
{ }^{1} \mathrm{HNMR}(\mathrm{ppm}): 9.21(\mathrm{~s}, 1 \mathrm{H},-\mathrm{NH}-\mathrm{C}=0), 7.26-8.21\left(\mathrm{~m}, 12 \mathrm{H} \text {, aromatic), } 7.1-7.6(\mathrm{~d}, 2 \mathrm{H}, \mathrm{CH}=\mathrm{CH}=\mathrm{C}=0), 2.37\left(\mathrm{~s}, 3 \mathrm{H},-\mathrm{CH}_{3}\right)\right. \\
\text { IR }\left(\mathrm{cm}^{-1}\right): 3030(-\mathrm{CH} \text { of alkene), } 1751(\mathrm{C}=0 \text { of acetic ester), } 1730(\mathrm{C}=0 \text { of benzoic ester }), 1626(\mathrm{C}=0 \text { of amide), } 1601(\mathrm{C}=\mathrm{C}) \\
\text { trans-alkene, } 3290(\mathrm{NH}), 1078 \text { aromatic }(\mathrm{C}-\mathrm{Cl}) \text { stretching vibration }\end{array}$ \\
\hline & 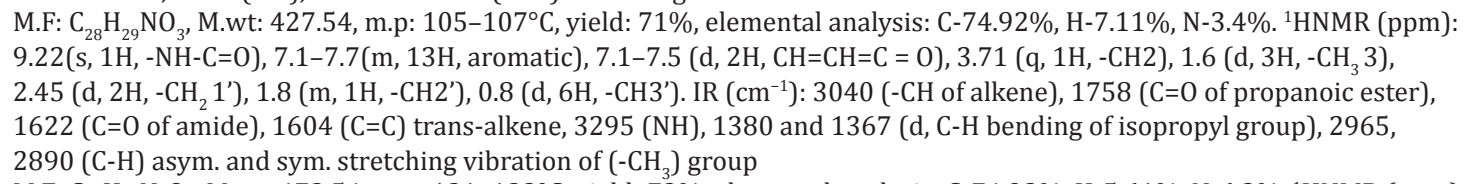 \\
\hline & $\begin{array}{l}\text { M.F: } \mathrm{C}_{28} \mathrm{H}_{28} \mathrm{~N}_{2} \mathrm{O}_{5}, \text { M.wt: } 472.54, \mathrm{~m} . \mathrm{p}: 121-123^{\circ} \mathrm{C} \text {, yield: } 73 \% \text {, elemental analysis: } \mathrm{C}-74.92 \%, \mathrm{H}-5.61 \%, \mathrm{~N}-6.2 \% .{ }^{1} \mathrm{HNMR}(\mathrm{ppm}): \\
9.22(\mathrm{~s}, 1 \mathrm{H},-\mathrm{NH}-\mathrm{C}=0), 7.12-8.39\left(\mathrm{~m}, 12 \mathrm{H}, \text { aromatic), } 7.35-7.76(\mathrm{~d}, 2 \mathrm{H}, \mathrm{CH}=\mathrm{CH}=\mathrm{C}=\mathrm{O}), 3.7(\mathrm{q}, 1 \mathrm{H},-\mathrm{CH} 2), 1.58\left(\mathrm{~d}, 3 \mathrm{H},-\mathrm{CH}_{3} 3\right),\right. \\
2.43\left(\mathrm{~d}, 2 \mathrm{H},-\mathrm{CH}_{2} \mathrm{1}^{\prime}\right), 1.82\left(\mathrm{~m}, 1 \mathrm{H},-\mathrm{CH} 2^{\prime}\right), 0.88\left(\mathrm{~d}, 6 \mathrm{H},-\mathrm{CH} 3^{\prime}\right) . \mathrm{IR}\left(\mathrm{cm}^{-1}\right): 3036(-\mathrm{CH} \text { of alkene), } 1758(\mathrm{C}=\mathrm{O} \text { of propanoic ester), } \\
1625(\mathrm{C}=\mathrm{O} \text { of amide), } 1602(\mathrm{C}=\mathrm{C}) \text { trans-alkene, } 3290(\mathrm{NH}), 1382 \text { and } 1367(\mathrm{~d}, \mathrm{C}-\mathrm{H} \text { bending of isopropyl group), } 2960, \\
2885(\mathrm{C}-\mathrm{H}) \text { asym. and sym. stretching vibration of }-\mathrm{CH}_{3} \text { group, } 1550(\mathrm{~N}-\mathrm{O}) \text { asym. stretching, } 1340(\mathrm{~N}-\mathrm{O}) \text { sym. stretching }\end{array}$ \\
\hline & $\begin{array}{l}\text { M.F: } \mathrm{C}_{28} \mathrm{H}_{28} \mathrm{ClNO}_{3}, \text { M.wt: } 461.99, \mathrm{~m} . \mathrm{p}: 112-114^{\circ} \mathrm{C} \text {, yield: } 71 \% \text {, elemental analysis: } \mathrm{C}-75.95 \%, \mathrm{H}-5.81 \%, \mathrm{~N}-3.2 \% \text {. } \\
{ }^{1} \mathrm{HNMR}(\mathrm{ppm}): 9.22(\mathrm{~s}, 1 \mathrm{H},-\mathrm{NH}-\mathrm{C}=\mathrm{O}), 7.12-7.7(\mathrm{~m}, 12 \mathrm{H} \text {, aromatic), } 7.05-7.62(\mathrm{~d}, 2 \mathrm{H}, \mathrm{CH}=\mathrm{CH}=\mathrm{C}=\mathrm{O}), 3.71(\mathrm{q}, 1 \mathrm{H},-\mathrm{CH} 2), \\
1.58\left(\mathrm{~d}, 3 \mathrm{H},-\mathrm{CH}_{3} 3\right), 2.43\left(\mathrm{~d}, 2 \mathrm{H},-\mathrm{CH}_{2} 1^{\prime}\right), 1.82\left(\mathrm{~m}, 1 \mathrm{H},-\mathrm{CH} 2^{\prime}\right), 0.88\left(\mathrm{~d}, 6 \mathrm{H},-\mathrm{CH} 3^{\prime}\right) . \mathrm{IR}\left(\mathrm{cm}^{-1}\right): 3045(-\mathrm{CH} \text { of alkene), } 1761(\mathrm{C}=0 \\
\text { of propanoic ester), } 1622(\mathrm{C}=\mathrm{O} \text { of amide), } 1600(\mathrm{C}=\mathrm{C}) \text { trans-alkene, } 3300(\mathrm{NH}), 1380 \text { and } 1365(\mathrm{~d}, \mathrm{C}-\mathrm{H} \text { bending of isopropyl } \\
\text { group), 2950, } 2875(\mathrm{C}-\mathrm{H}) \text { asym. and sym. stretching vibration of }-\mathrm{CH}_{3} \text { group, } 1080 \text { aromatic }(\mathrm{C}-\mathrm{Cl}) \text { stretching vibration }\end{array}$ \\
\hline & $\begin{array}{l}\text { M.F: } \mathrm{C}_{24} \mathrm{H}_{19} \mathrm{NO}_{5}, \mathrm{M} . \mathrm{wt}: 401.42 \text {, m.p: } 138-140^{\circ} \mathrm{C} \text {, yield: } 66 \% \text {, elemental analysis: } \mathrm{C}-67.98 \%, \mathrm{H}-4.93 \%, \mathrm{~N}-3.65 \% .{ }^{1} \mathrm{HNMR}(\mathrm{ppm}): \\
9.22(\mathrm{~s}, 1 \mathrm{H},-\mathrm{NH}-\mathrm{C}=0), 7.05-8.25\left(\mathrm{~m}, 13 \mathrm{H} \text {, aromatic), } 7.05-7.62(\mathrm{~d}, 2 \mathrm{H}, \mathrm{CH}=\mathrm{CH}=\mathrm{C}=\mathrm{O}), 2.39\left(\mathrm{~s}, 3 \mathrm{H},-\mathrm{CH}_{3}\right) . \mathrm{IR}\left(\mathrm{cm}^{-1}\right):\right. \\
3030(-\mathrm{CH} \text { of alkene), } 1748(\mathrm{C}=0 \text { of acetic ester), } 1725(\mathrm{C}=0 \text { of benzoic ester }), 1622(\mathrm{C}=0 \text { of amide), } 1600(\mathrm{C}=\mathrm{C}) \\
\text { trans-alkene, } 3300(\mathrm{NH}), 2940,2865(\mathrm{C}-\mathrm{H}) \text { asym. and sym. stretching vibration of }-\mathrm{CH}_{3} \text { group }\end{array}$ \\
\hline & 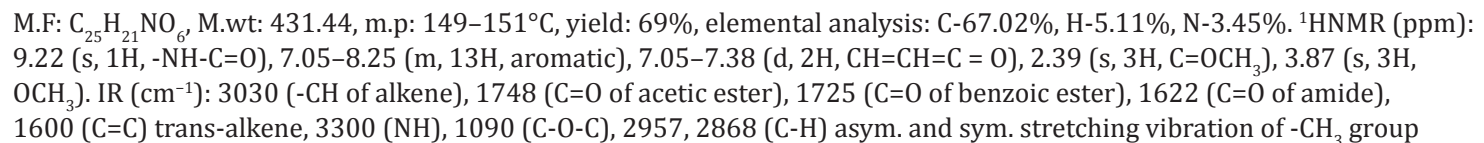 \\
\hline & 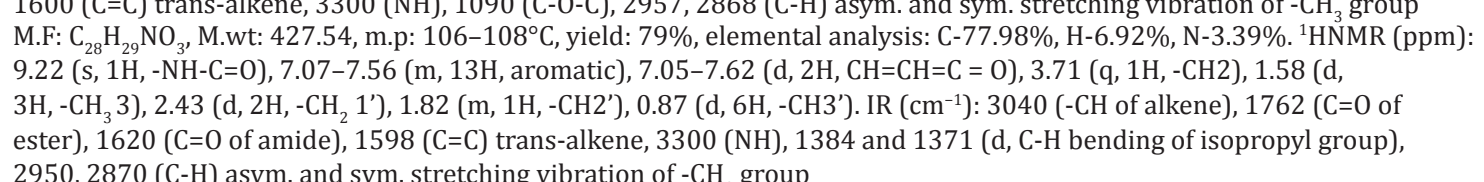 \\
\hline & 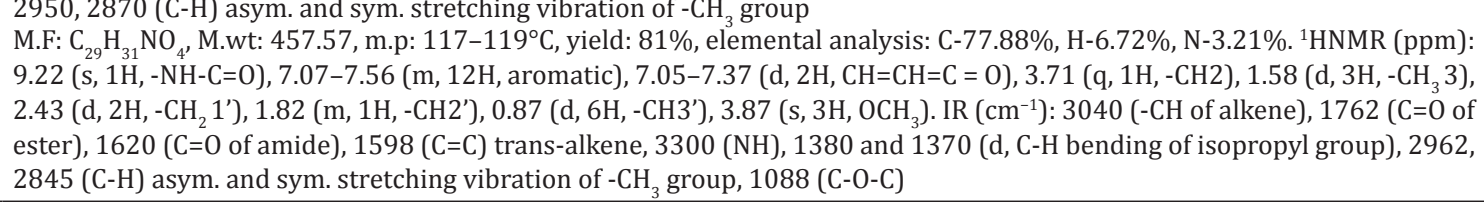 \\
\hline
\end{tabular}




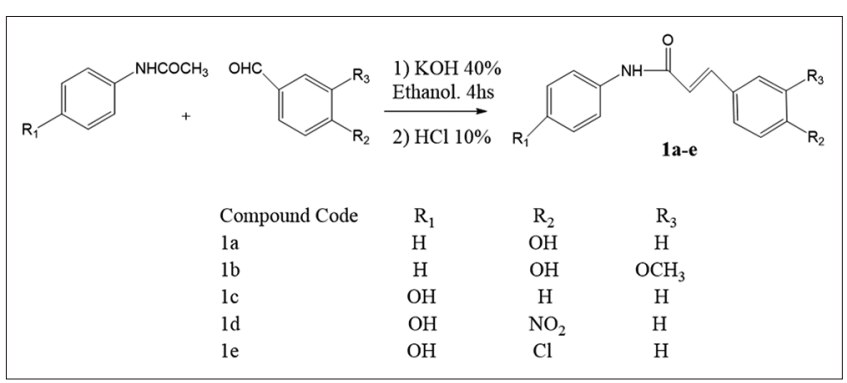

Scheme 1: Chemical synthesis of compounds 1a-e

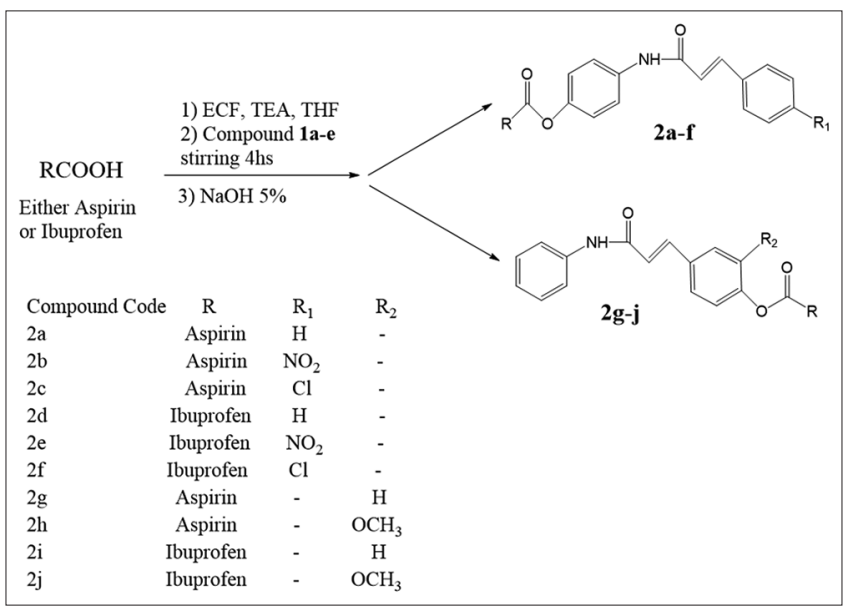

Scheme 2: Chemical synthesis of compounds 2a-j

Table 2: Antimicrobial activity of compounds (2a-j) by cup plate method

\begin{tabular}{|c|c|c|c|}
\hline \multirow[t]{2}{*}{ Compound $(200 \mu \mathrm{g} / \mathrm{mL})$} & \multicolumn{3}{|c|}{ Zone of inhibition } \\
\hline & S. aureus & E. coli & C. albicans \\
\hline $2 a$ & 18 & 16 & 10 \\
\hline $2 b$ & 17 & 15 & 12 \\
\hline $2 c$ & 16 & 19 & 18 \\
\hline $2 \mathrm{~d}$ & 13 & --- & 5 \\
\hline $2 \mathrm{e}$ & 15 & --- & 6 \\
\hline $2 \mathrm{f}$ & --- & 12 & 9 \\
\hline $2 \mathrm{~g}$ & 15 & 18 & 12 \\
\hline $2 \mathrm{~h}$ & 16 & 14 & 9 \\
\hline $2 \mathrm{i}$ & --- & 11 & 5 \\
\hline $2 \mathrm{j}$ & 12 & --- & --- \\
\hline Ampicillin & 20 & 21 & --- \\
\hline Ketoconazole & --- & --- & 20 \\
\hline Solvent control (DMSO) & --- & --- & --- \\
\hline
\end{tabular}

---: Inactive. Results represent the average of triplicate experiments. S. aureus: Staphylococcus aureus, E. coli: Escherichia coli, C. albicans: Candida albicans

distilled water to obtain compounds 1a-e. These compounds were recrystallized from ethanol.

\section{Chemical synthesis of compounds $2 a-j[25,26]$}

The synthesis of these compounds was achieved by reacting compounds 1a-e by mixed anhydride method with either ibuprofen or aspirin using ECFasa catalyst, as shown in Scheme 2.

NSAID (either aspirin or ibuprofen) ( $0.01 \mathrm{~mol}$ ) was dissolved in $30 \mathrm{~mL}$ of dry tetrahydrofuran (THF) containing triethylamine $(0.01 \mathrm{~mol})$ and placed in a refrigerator at -5 to $-10^{\circ} \mathrm{C}$. A solution of ECF $(0.01 \mathrm{~mol})$ was added dropwise to the above mixture over a period of $10 \mathrm{~min}$ with continuous stirring, which maintained for further $30 \mathrm{~min}$. Compound 1a-e $(0.01 \mathrm{~mol})$ was dissolved in $30 \mathrm{~mL}$ THF previously cooled to $0^{\circ} \mathrm{C}$ and was added dropwise over $10 \mathrm{~min}$ to the above mixture with stirring for $4 \mathrm{~h}$. The solvent was then evaporated, and the resultant precipitate was washed with cold $\mathrm{NaOH}$ solution $(5 \%)$ and distilled water

\section{In vitro antimicrobial screening}

The synthesized compounds were evaluated for their antimicrobial activity using cup plate method for a zone of inhibition against Staphylococcus aureus, Escherichia coli, and Candida albicans $[27,28]$. Compounds (2a-j) and standard drugs (ampicillin and ketoconazole) were screened at a concentration of $200 \mu \mathrm{g} / \mathrm{mL}$; additionally, dimethyl sulfoxide was used as a control. In this procedure, melted agar was poured into a sterile Petri dish and inoculated with the microorganisms. Using a sterile cork borer, wells $(8 \mathrm{~mm})$ were made on the surface of an agar plate and a specific volume of the screened substances is poured in them, plates were incubated at a temperature of $37^{\circ} \mathrm{C}$ for $48 \mathrm{~h}$. The diameter of this zone $(\mathrm{mm})$ was measured and shown in Table 2 .

\section{RESULTS AND DISCUSSION}

Physical data, including molecular formula (M.F), molecular weights (M.wt), melting points (m.p), and spectral data along with antimicrobial activity, are shown in Tables 1 and 2, respectively. The chemical structures of the synthesized compounds were confirmed by spectrophotometric analysis (FTIR, ${ }^{1} \mathrm{HNMR}$, and elemental analysis). The most significant characteristic IR bands that confirm the formation of compounds (1a-e) are the appearance of $\mathrm{C}=\mathrm{C}$ stretching band around $1600 \mathrm{~cm}^{-1}$, shift in $\mathrm{C}=\mathrm{O}$ stretching band to a lower wave number because of the conjugation with aromatic double bond, the disappearance of symmetrical and asymmetrical stretching bands of substituted acetanilide $\left(\mathrm{CH}_{3}\right)$ group, and the appearance of other bands regarding each compound (such as $\mathrm{OH}$ stretching for compound $1 \mathrm{~b}$ at $3125 \mathrm{~cm}^{-1}$ ) as shown in Table 1. Compounds (2a-j) are characterized by the appearance of new ester band which is affected by the conjugation with one or both sides. The change in chemical shifts, proton counting, integration, and spinspin splitting was distinguishable feature in ${ }^{1} \mathrm{HNMR}$, particularly the appearance of vinylic $(\mathrm{C}=\mathrm{C})$ protons at 7-7.8 $(\mathrm{ppm})$ downfield (because of delocalization of $\pi$ electrons which results in deshielding of these protons along with the inductive effect of the neighboring $\mathrm{C}=0$ group) and disappearance of $\mathrm{OH}$ protons due to ester formation [29].

The synthesized compounds were screened against bacterial and fungal strains. Compound $2 \mathrm{c}$ has the higher zone of inhibition for $E$. coli (19 $\mathrm{mm}$ ) and C. albicans $(18 \mathrm{~mm})$ and compound 2a has the higher zone of inhibition for S. aureus $(18 \mathrm{~mm})$. The higher activity of compound 2c may be attributed to its higher lipophilicity among the aspirin linked $\mathrm{N}$-phenylcinnamamide derivatives which may result in higher penetration through the microbial cell wall. Compounds (2f, $2 \mathrm{i}),(2 \mathrm{~d}, 2 \mathrm{e}, 2 \mathrm{j})$, and $2 \mathrm{j}$ show no activity on S. aureus, E. coli, and C. albicans, respectively. This could be explained by the bulkiness offered by the linking compounds 1a-e to ibuprofen which has a great effect on the penetration and consequently the activity of compounds $2 \mathrm{~d}, 2 \mathrm{e}, 2 \mathrm{f}, 2 \mathrm{i}$, and $2 \mathrm{j}$.

\section{CONCLUSION}

Compounds (2a-j) were successfully synthesized, confirmed (by elemental analysis, FTIR, and ${ }^{1}$ HNMR), and assessed for their antimicrobial activity. Regardless of the potential antimicrobial activity of the parent compounds (chalcones, aspirin, and ibuprofen), the synergism has not been achieved.

\section{AUTHOR'S CONTRIBUTION}

Ameer H. Alwashde signed the research, performed the synthesis of the compounds, and wrote the paper. Alaa M. Mahdi performed the elemental analysis, FTIR, and ${ }^{1} \mathrm{H}-\mathrm{NMR}$ spectroscopy. Haider J. AlKaragully performed the antimicrobial evaluation.

\section{CONFLICTS OF INTEREST}

The authors declare that they have no conflicts of interest. 


\section{REFERENCES}

1. Divyashanthi CM, Adithiyakumar S, Bharathi N. Study of prevalence and antimicrobial susceptibility pattern of bacterial isolates in a tertiary care hospital. Int J Pharm Pharm Sci 2015;7:185-90.

2. Begüm EA, Rahmiye E. Chemical and structural properties of chalcones I. FABAD J Pharma Sci 2011;36:223-42.

3. Kateb BA, Hussien AA, Baseer MA. Spectral studies and antimicrobial screening for some novel chalcones analogues. Int J Curr Pharma Res 2016;8:33-7.

4. Kostanecki SV, Tambor J. Synthese des fisetins. J Chem Ber 1921;32:1899.

5. Jalal HM. Biological activities importance of chalcone derivatives. Int J Chem Biomol Sci 2015;1:107-12.

6. Thatiana LV, Sanderson DC, Bárbara AV, Alessandra MS, Vinícius M, Palmeira M, et al. Antimycobacterial and anti-inflammatory activities of substituted chalcones focusing on an anti-tuberculosis dual treatment approach. Molecules 2015;20:8072-93.

7. Bukhari SN, Jasamai M, Jantan I, Ahmad W. Review of methods and various catalysts used for chalcone synthesis. Mini Rev Org Chem 2013;10:73-83.

8. Patole1 SS, Rajput SS. Synthesis characterization and biological evaluation of $(3 z, 4 z)-3$, 4-bis (substituted phenyl benzylidine)-1(4-subtituted phenyl) pyrolidine-2, 5-dione. Int J Pharm Pharm Sci 2016;8:286-91.

9. Hu Z, Liu J, Dong Z, Guo L, Wang D, Zeng P. Synthesis of chalcones catalyzedby SOCl2/EtOH. J Chem Res 2004;35:158-9.

10. Patil CB, Mahajan SK, Katti SA. Chalcone: A versatile molecule. J Pharm Sci Res 2009;1:11-22.

11. Prashar H, Chawla A, Sharma AK, Kharb R. Chalcone as a versatile moiety for diverse pharmacological activities. Int J Pharm Sci Res 2012;3:1913-27.

12. Chandrabose K, Narayana SH, Narayana MB, Sakthivel R, Uma V, Elangovan $\mathrm{M}$, et al. Advances in chalcones with anticancer activities. Recent Pat Anticancer Drug Discov 2015;10:97-115.

13. Bhat BA, Dhar KL, Puri SC, Saxena AK, Shanmugavel M, Qazi GN, et al. Synthesis and biological evaluation of chalcones and their derived pyrazoles as potential cytotoxic agents. Bioorg Med Chem Lett 2005; $15: 3177-80$.

14. Vibhute YB, Basser MA. Synthesis and activity of a new series of chalconesas antibacterial agents. Ind J Chem 2003;42B:202-5.

15. Pande A, Saxena VK. Synthesis and antiviral activity of 4(Arylhydrazono)-3-methyl-1-(3,5-dinitrobrnzoyl)-2-pyrazolin-5- ones. Ind J Chem 1987;26B:390-2.

16. Pandey VK, Gupta VD, Tiwari DN. Synthesis of substituted benzoxazines as potential antiviral agents. Ind J Het Chem 2004;13:399-400.

17. Gupta U, Sareen V, Khatri V, Chugh S. Synthesis and antifungal activity of new fluorine containing 4-(substituted Phenyl azo) pyrazolesand isoxazoles. Ind J Het Chem 2005;14:265-6.

18. Mishra RM, Wahab A. Synthesis and fungicidal activity of some new 2, 3-dihydro-4h-benzimidazolo [3, 2-b] - [1, 3] - thiazine-4ones. Ind J Het Chem 2003;13:29-32.

19. Mainous AG $3^{\text {rd }}$, Pearson WS. Aspirin and ibuprofen: Potential mediators of the cardiovascular risk due to smoking. Fam Med 2003;35:112-8.

20. Jayakumari S, Krishna AG. Prescription pattern analysis of antiinflammatory drugs in general medicine and surgery department at a tertiary care hospital. Int J Pharm Pharm Sci 2016;8:114-8.

21. McEvoy GK, Litvak K, Welsh OH, Dewey DR, Fong PA, Douglas PM, et al. AHFS Drug Information. Bethesda: American Society of Hospital Pharmacists; 1993.

22. Al-Bakri AG, Othman G, Bustanji Y. The assessment of the antibacterial and antifungal activities of aspirin, EDTA and aspirinEDTA combination and their effectiveness as antibiofilm agents. J App Micro 2009; 107:280-6.

23. Husseinand AAS, AL-Janabi S. In vitro antibacterial activity of ibuprofen and acetaminophen. J Gloinf Dis 2010;2:105-8.

24. Rohini RM, Kalpana D, Simi D. Synthesis of novel phenyl azo chalcone derivatives for ant tubercular, anti-inflammatory and antioxidant activity. Pharm Chem 2015;7:77-83.

25. Rho S, Baek HS, Kim DH, Chang IS. A convenient method for the preparation of alkanolamides. Bull Korean Chem Soc 2006;27:584-6.

26. Shakir MA, Ameer HK. Synthesis of new cephalosporins of expected improved activity and resistance against $\beta$-lactamases, Iraqi. J Pharm Sci 2014;23:24-32

27. Jennifer F, Abhishek K, Pankaj K, Satyajeet S, Bhatt M, Bhakta R, et al. Synthesis, anti-inflammatory and antimicrobial activity of some carboxyamide derivatives of naproxen. World J Pharm Pharm Sci 2014;3:2026-34.

28. Bairam R, Muppavarapu SM, Sreekanth S. Synthesis, characterization, biological evaluation and docking of some novel substituted 1, 3-thiazine derivatives. Int J Pharm PharmSci 2017;9:233-42.

29. Silverstein RM, Webster FX, Kiemle DJ. Spectrometric Identification of Organic Compounds. $7^{\text {th }}$ ed. UAS: John Wiley \& Sons; 2005. p. 144-216. 